\title{
New Radiocarbon Dates from East Texas Caddo Sites
}

Timothy K. Perttula

Heritage Research Center, Stephen F. Austin State University

Robert Z. Selden Jr.

Heritage Research Center, Stephen F. Austin State University

Follow this and additional works at: https://scholarworks.sfasu.edu/ita

Part of the American Material Culture Commons, Archaeological Anthropology Commons, Environmental Studies Commons, Other American Studies Commons, Other Arts and Humanities Commons, Other History of Art, Architecture, and Archaeology Commons, and the United States History Commons

Tell us how this article helped you.

This Article is brought to you for free and open access by the Center for Regional Heritage Research at SFA ScholarWorks. It has been accepted for inclusion in Index of Texas Archaeology: Open Access Gray Literature from the Lone Star State by an authorized editor of SFA ScholarWorks. For more information, please contact cdsscholarworks@sfasu.edu. 


\section{New Radiocarbon Dates from East Texas Caddo Sites}

Creative Commons License

(c) (i) (8)

This work is licensed under a Creative Commons Attribution-NonCommercial 4.0 International License 


\title{
New Radiocarbon Dates from East Texas Caddo Sites
}

\author{
Timothy K. Perttula and Robert Z. Selden, Jr.
}

\section{INTRODUCTION}

In this article, we report on new radiocarbon dates obtained from five Caddo sites in East Texas. The radiocarbon samples are charred organic remains scraped off of one surface of whole vessels or sherds. These samples are from the Johns (41CP12), Shelby Mound (41CP71), Gilbert (41RA13), Henry Spencer (41UR315), and Henry Williams (41UR318) sites. All of the dates are calibrated using OxCal v4.1.7 (Bronk Ramsey 2012), with atmospheric data from Reimer et al. (2009).

\section{THE DATES}

The new date from the Johns site, a Late Caddo, Titus phase cemetery in the Big Cypress Creek drainage (Perttula et al. 2010), is on organic residues scraped from the interior surface of Vessel 3 in Burial 16. This is a large grog-tempered jar with closely-spaced horizontal incised lines on the rim, while the vessel body has diagonal brushing marks. The 2-sigma ( $95.4 \%$ probability) calibrated age range of the organic residue on the vessel is A.D. 1461-1635, with a median calibrated age of A.D. 1558 (Figure 1).

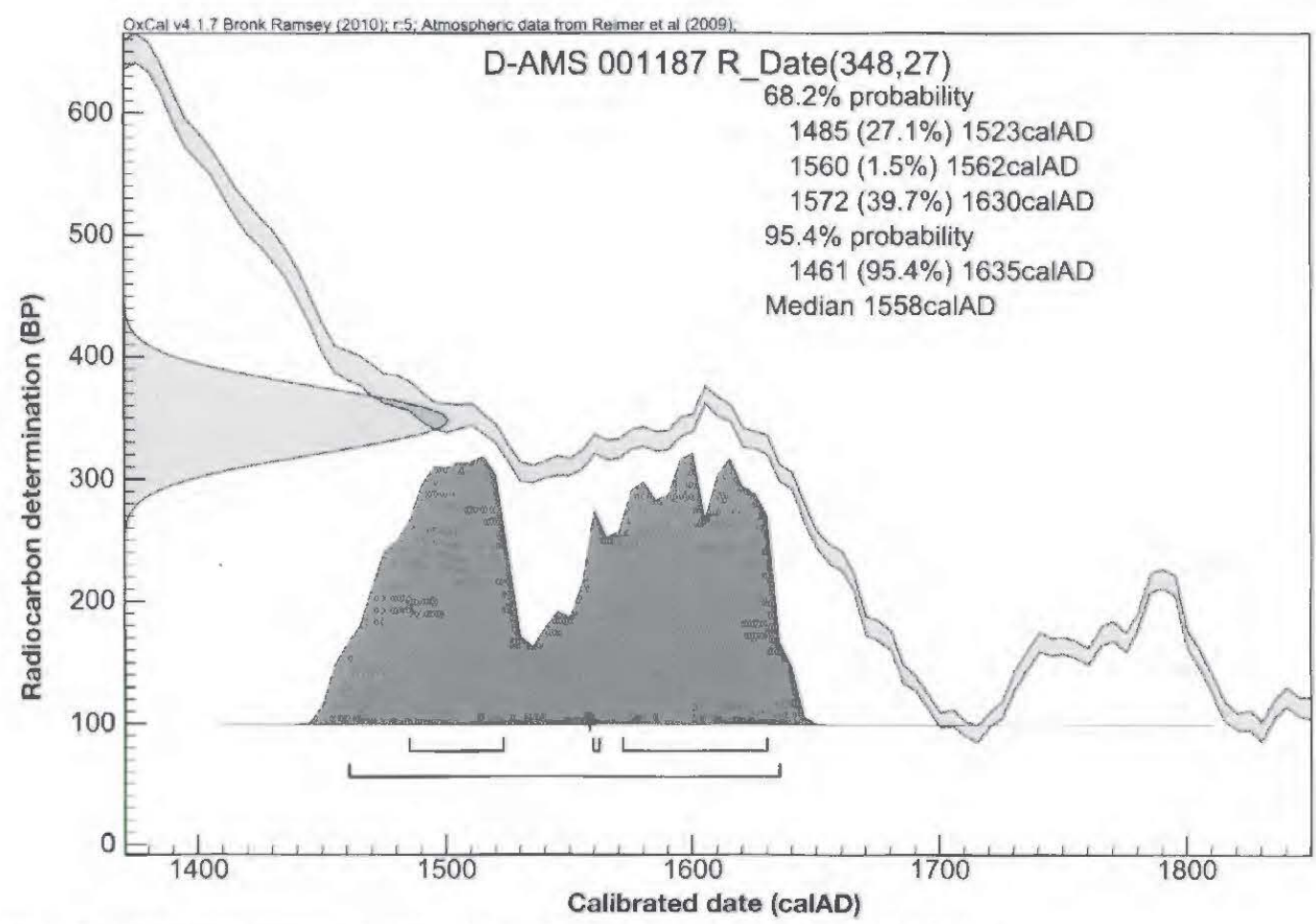

Figure 1. Calibrated age ranges of Johns (41CP12) Vessel 3, Burial 16 (AMS-001187). 
The Shelby Mound site (41CP71) is a Late Caddo, Titus phase mound center, community cemetery, and large village on Greasy Creek in the Big Cypress Creek drainage (Perttula et al. 2012a). Organic residue was collected from a medium-sized jar with an incised rim and appliqued lug handles. There are four sets of appliqued nodes on the body (Figure 2).

The 2-sigma calibrated age ranges of the organic residue with the highest probabilities are A.D. 15121602 and A.D. 1616-1665 (Figure 3). The median calibrated age is A.D. 1572.

Charred organic residues were taken from a plain grog-tempered body sherd recovered in Feature B3 at the Gilbert site (4IRA13). The Gilbert site is an mid-1 $8^{\text {th }}$ century Caddo site on Lake Fork Creek in the upper Sabine River basin (Blaine 1992; Jelks 1967; Perttula 2012).

Figure 2. Incised-appliqued jar from the Shelby Mound site (\#241 in Margaret Hinton collection).
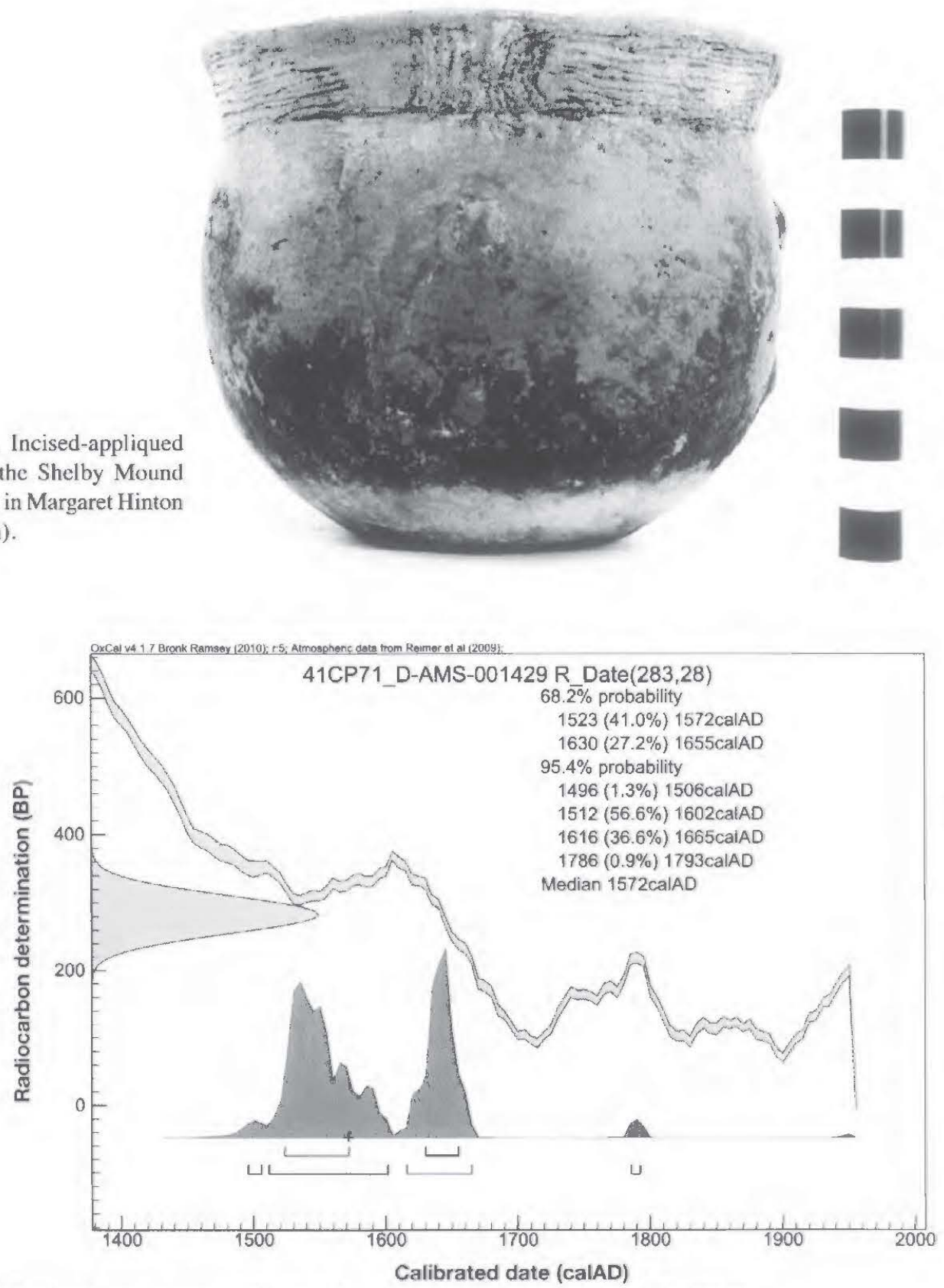

Figure 3. Calibrated age ranges of Shelby Mound (41CP71) Vessel \#241 (AMS-001429). 
The organic residue on the sherd has 2-sigma age ranges of A.D. 1642-1678 and A.D. 1765-1800 (Figure 4), with a median calibrated age of A.D. 1745. The stable carbon isotope value of $-12.1 \mathrm{o} / \mathrm{oo}$ on the organic residue indicates that the residue came from maize remains charred on the vessel, likely a jar.

There are three new radiocarbon dates from the Henry Spencer site, primarily a Late Caddo, Titus phase cemetery (Perttula et al. 2012b), on a tributary to Little Cypress Creek. The first date is organic residue from an incised-punctated jar dubbed Spencer Incised-Punctated (Figure 5). The 2-sigma calibrated age ranges of the organic residue with the highest probabilities are A.D. 1445-1524 and A.D. 1570-1631, with a median calibrated age of A.D. 1498 (Figure 6).

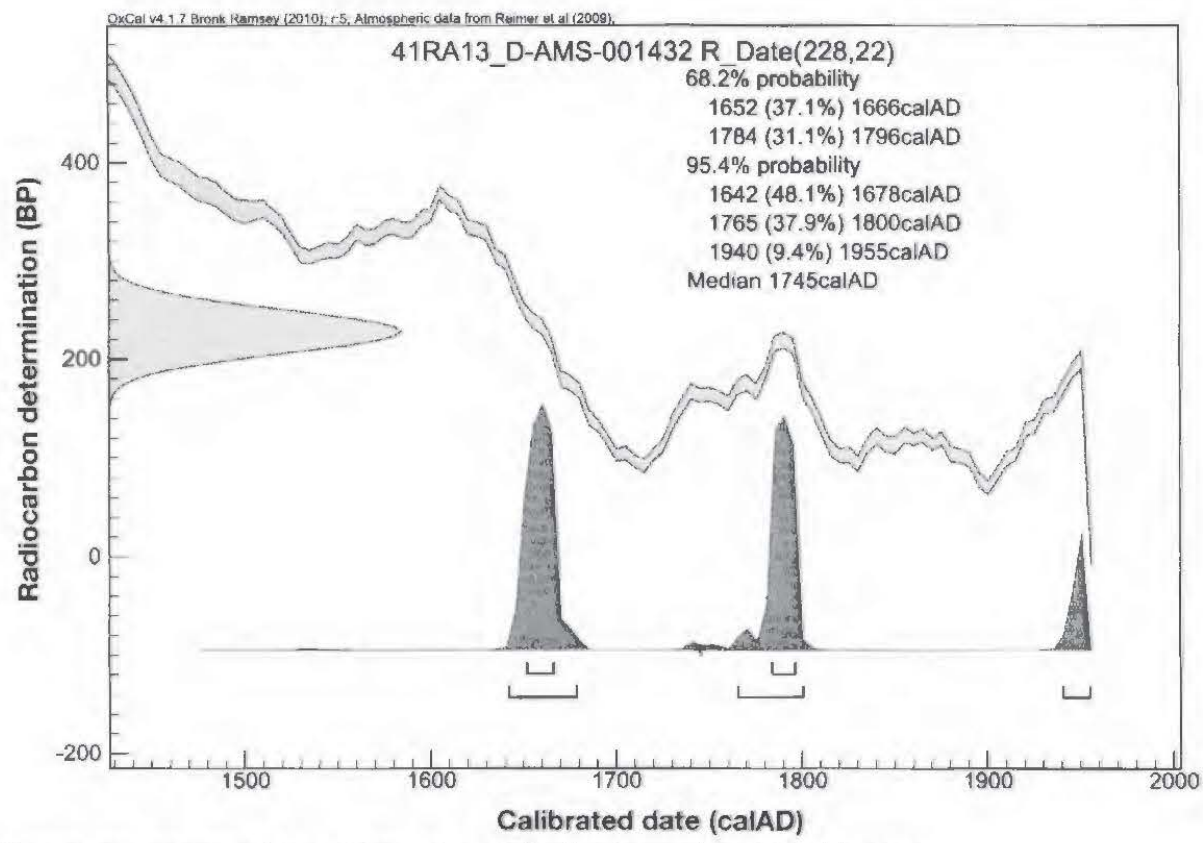

Figure 4. Calibrated age ranges of the Gilbert (41RA13) sherd sample (AMS-001432).

Figure 5. Incised-punctated jar, Burial 33, Vessel 186, from the Henry Spencer site.
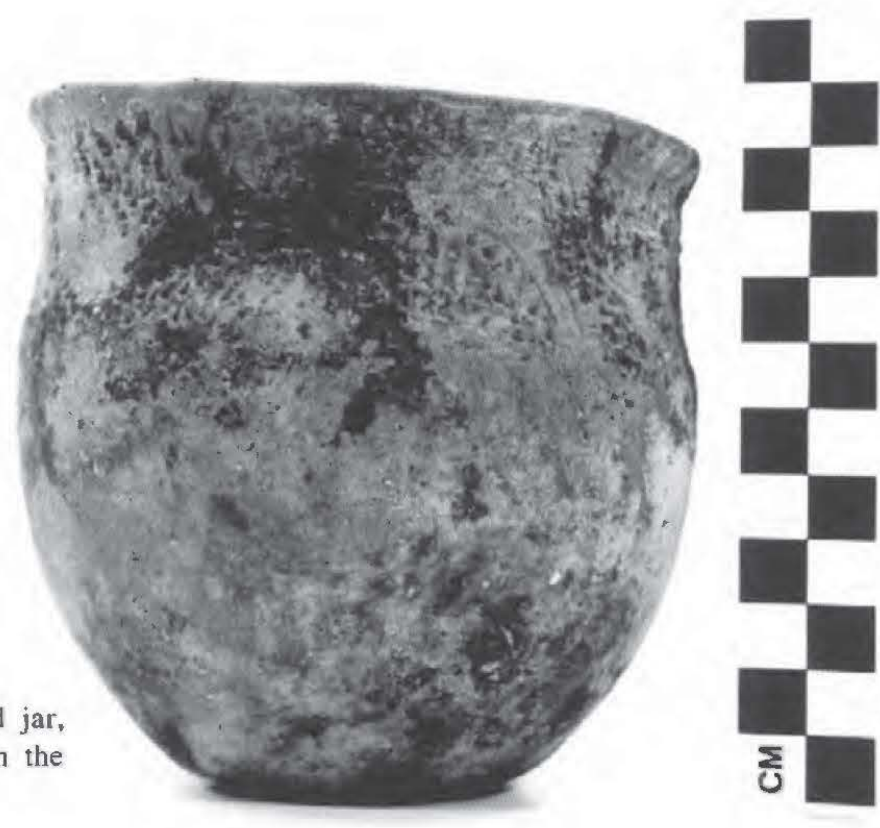


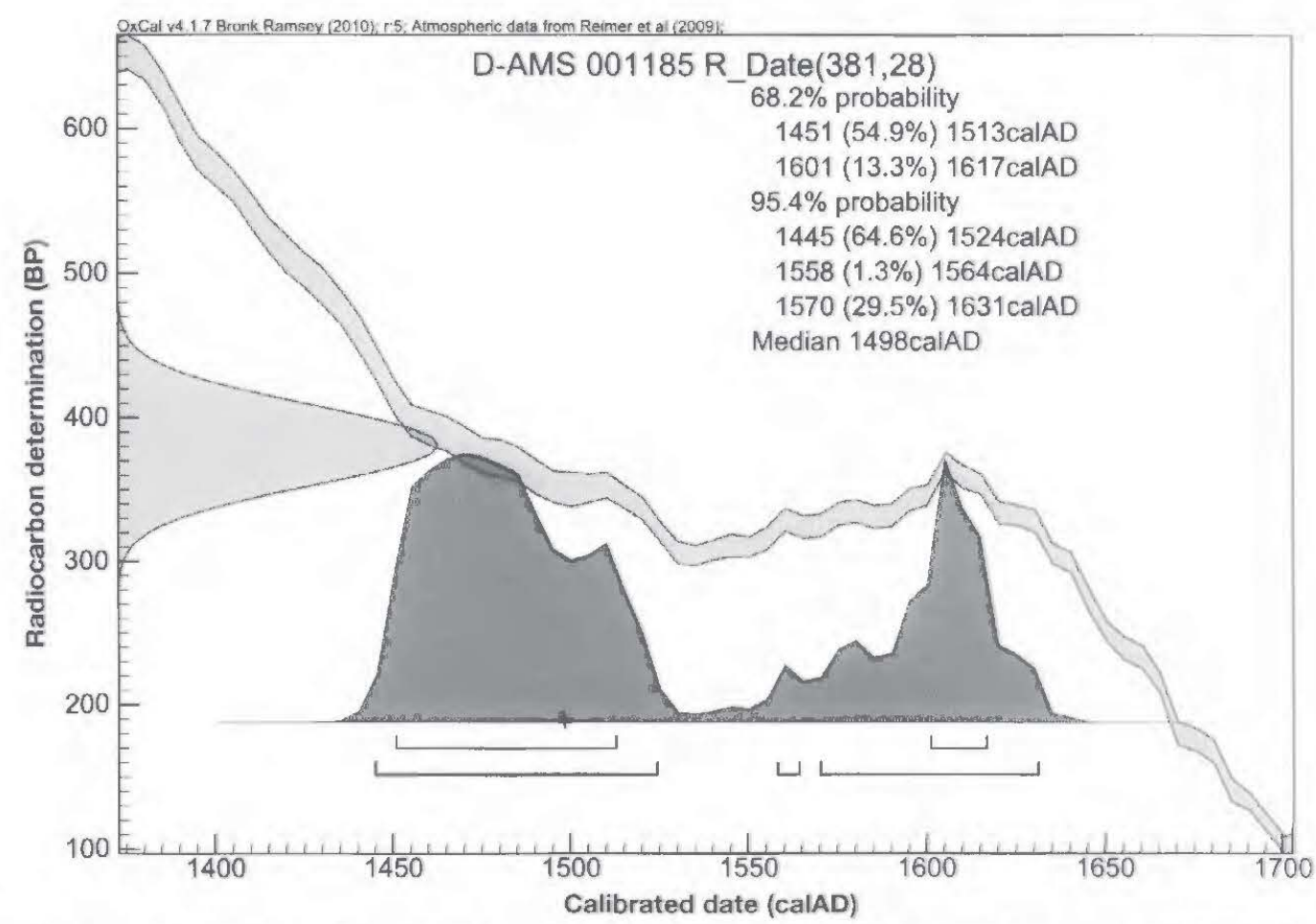

Figure 6. Calibrated age ranges of Burial 33, Vessel 186 organic residue from the Henry Spencer site (AMS-001185).

The second new radiocarbon from the Henry Spencer site is on organic residue from a medium-sized jar with appliqued-punctated and incised decorative elements (Vessel 7, Burial 2) (Figure 7). The 2 sigmacalibrated age ranges of the organic residue on this vessel are A.D. 1278-1315 and A.D. 1355-1389, with a median calibrated age of A.D. 1311. Based on other vessels recovered from this burial (Perttula et al. 2012b:20-25), this date appears to be anomalously older than expected, by perhaps 150-200 years or more.

Figure 7. Appliqued-punctated and incised jar, Burial 2, Vessel 7, from the Henry Spencer site.

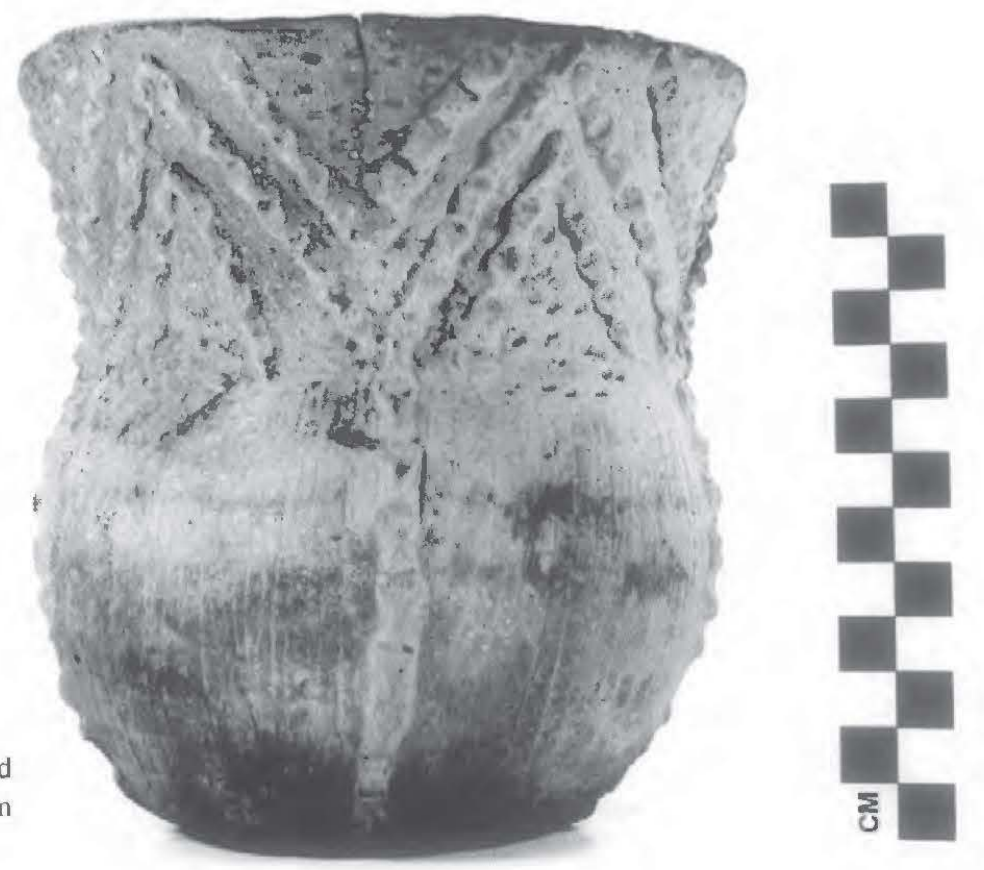




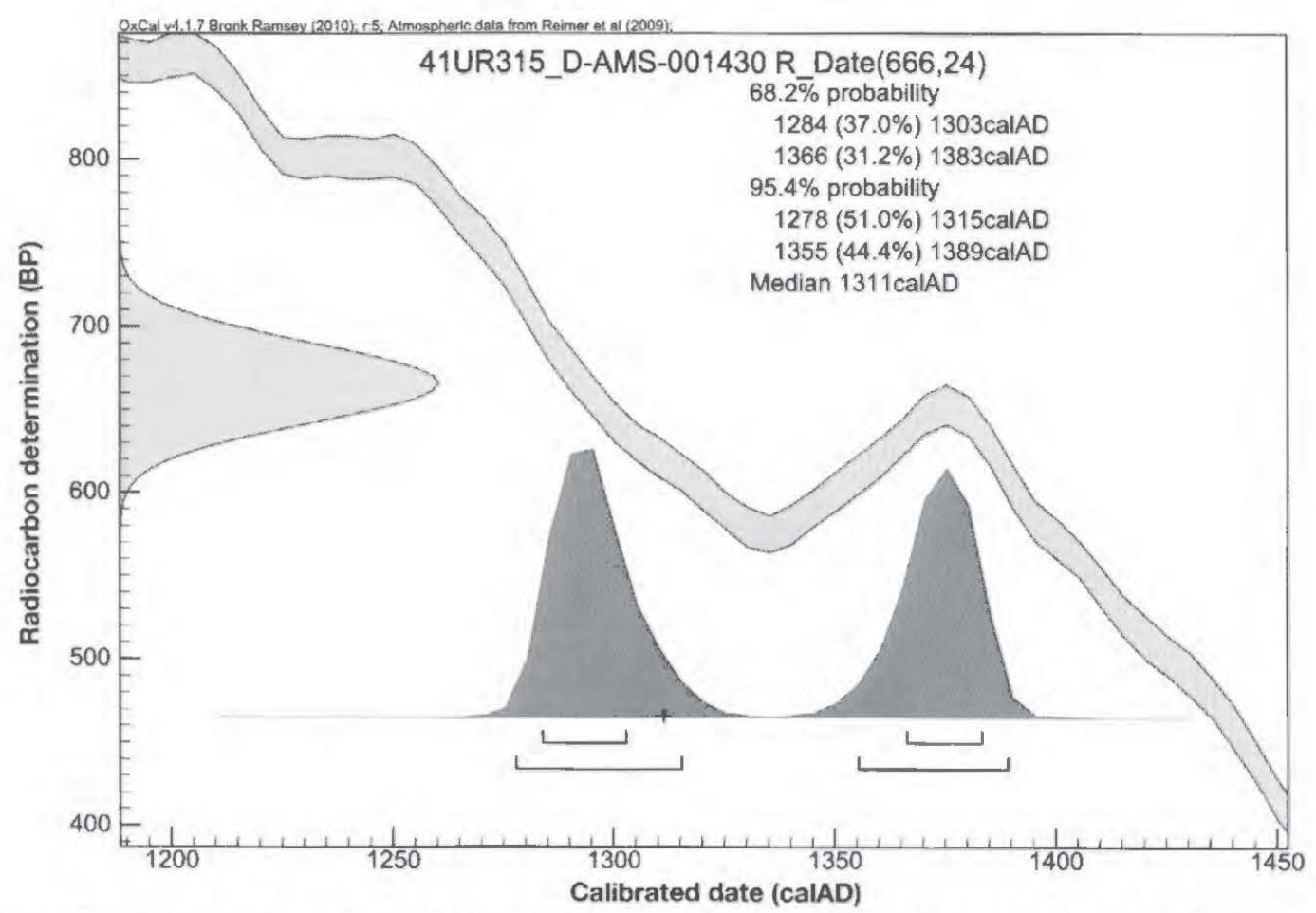

Figure 8. Calibrated age ranges of Burial 2, Vessel 7 organic residue from the Henry Spencer site (AMS-001430).
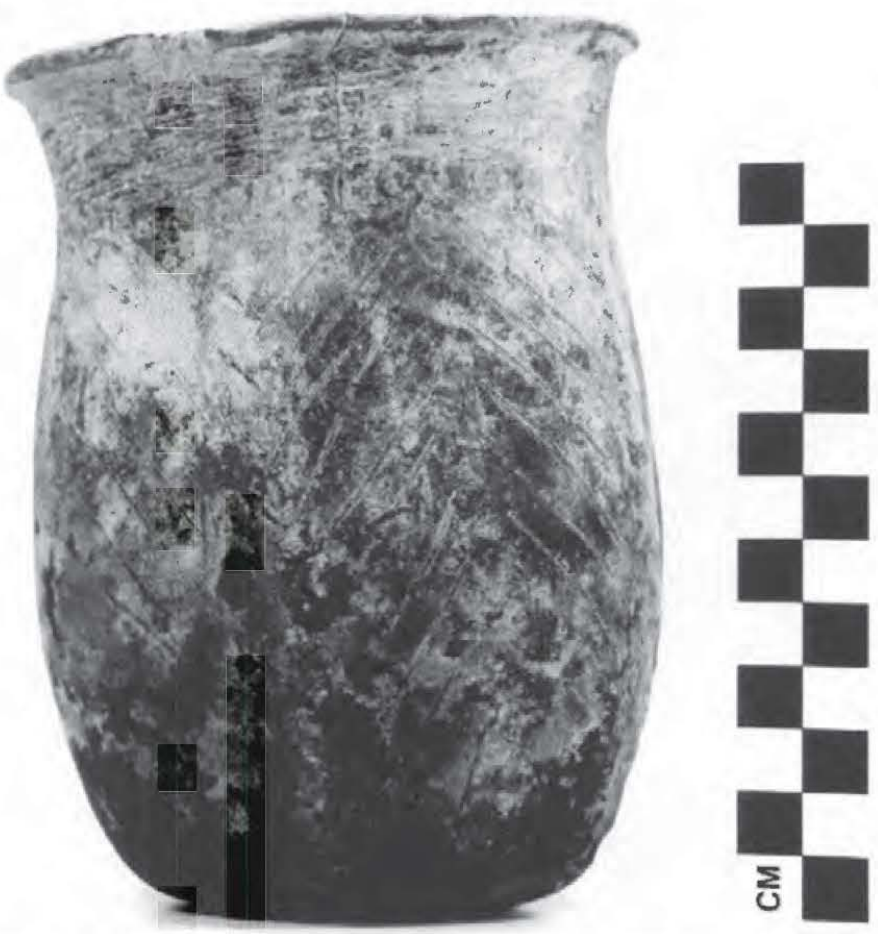

Figure 9. Pease Brushed-Incised jar, Vessel 87, Burial 18, from the Henry Spencer site.
The third new radiocarbon date from the Henry Spencer is from a Pease Brushed-Incised jar (Vessel 87) from Burial 18 (Figure 9). The calibrated age ranges on the vessel organic residue with the highest probabilities are A.D. 1449-1524 and A.D. 1570-1631, with a calibrated median age of A.D. 1507 (Figure 10).

The final new radiocarbon date is from the organic residue scraped from a Harleton Appliqued jar (Figure 11) in Burial 20 (Vessel 2003.08.1042) at the Henry Williams site (41UR318). Henry Williams is a large Late Caddo habitation and cemetery locale on Gum Creek in the Little Cypress Creek basin (Perttula et al. 2012c). It is only a few miles from the Henry Spencer site.

The 2-sigma calibrated age ranges for the organic residue on this vessel are A.D. 1341-1395 and A.D. 1285-1328, with a median calibrated age of A.D. 1354 (Figure 12). Based on other vessels recovered in the cemetery, this date appears to be anomalously older than expected, by perhaps $150-200$ years or more. 


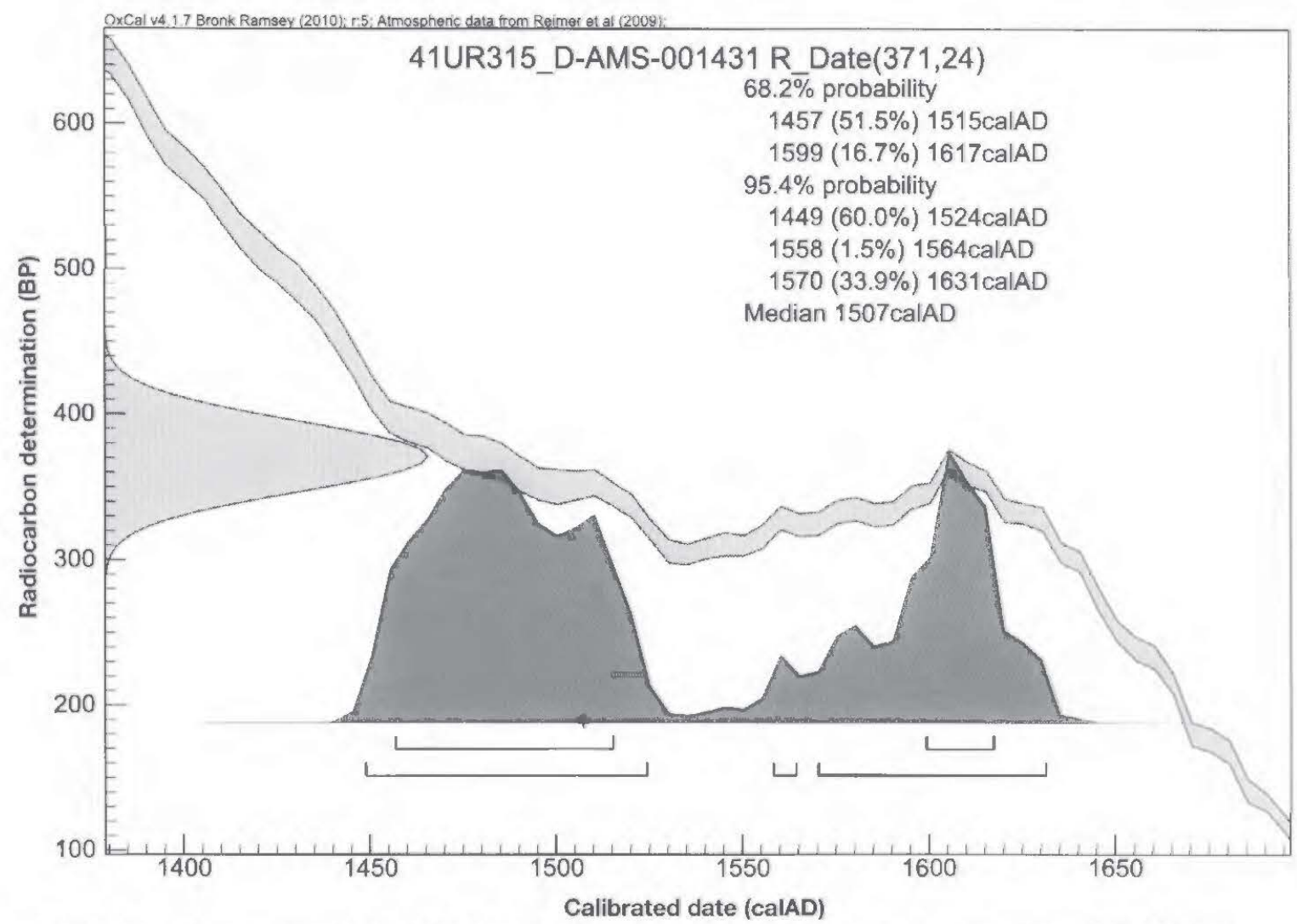

Figure 10. Calibrated age ranges of Burial 18, Vessel 87 organic residue from the Henry Spencer site (AMS-001431).

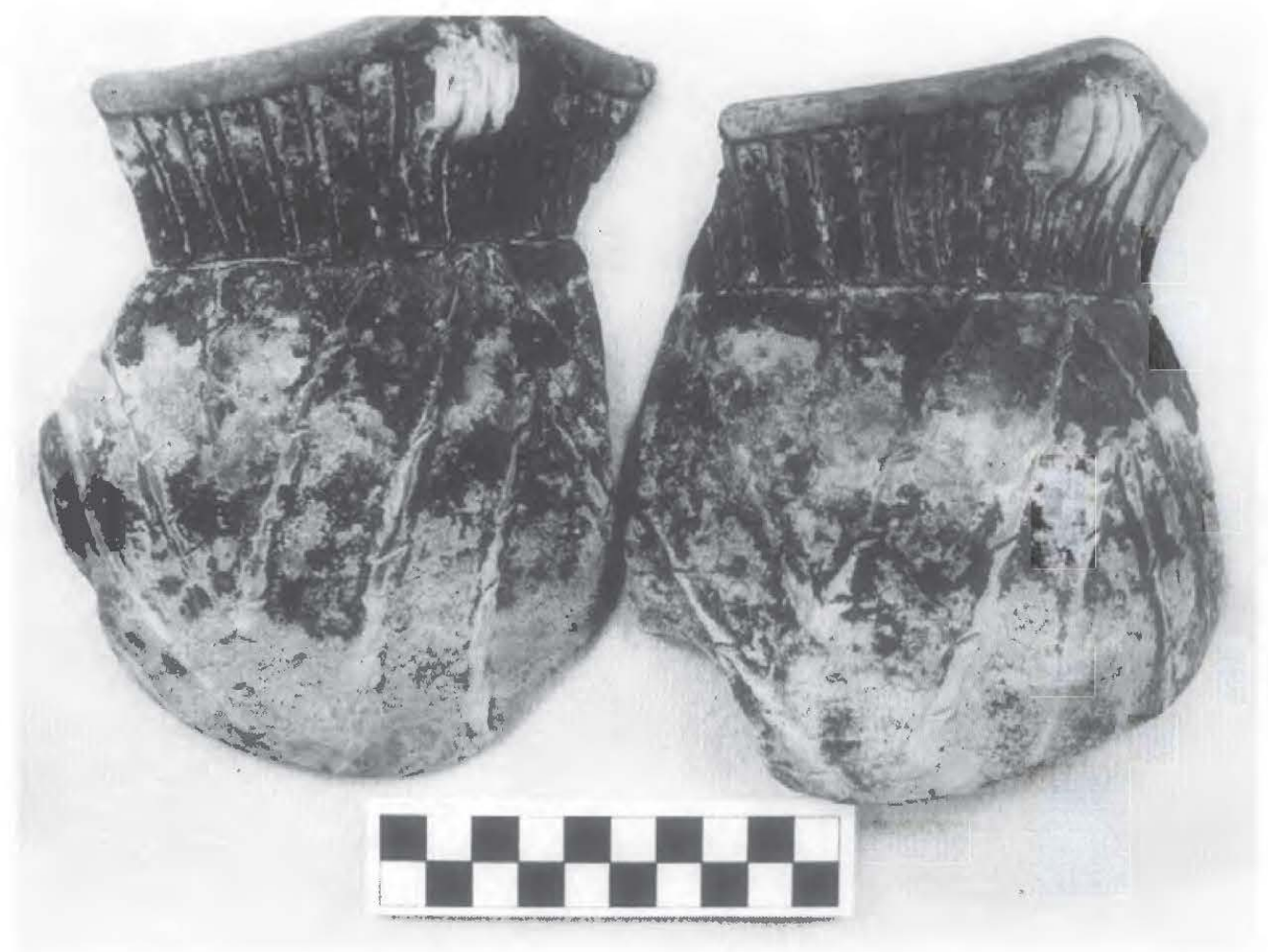

Figure 11. Harleton Appliqued jar from Burial 20 at the Henry Williams site (41UR318). 


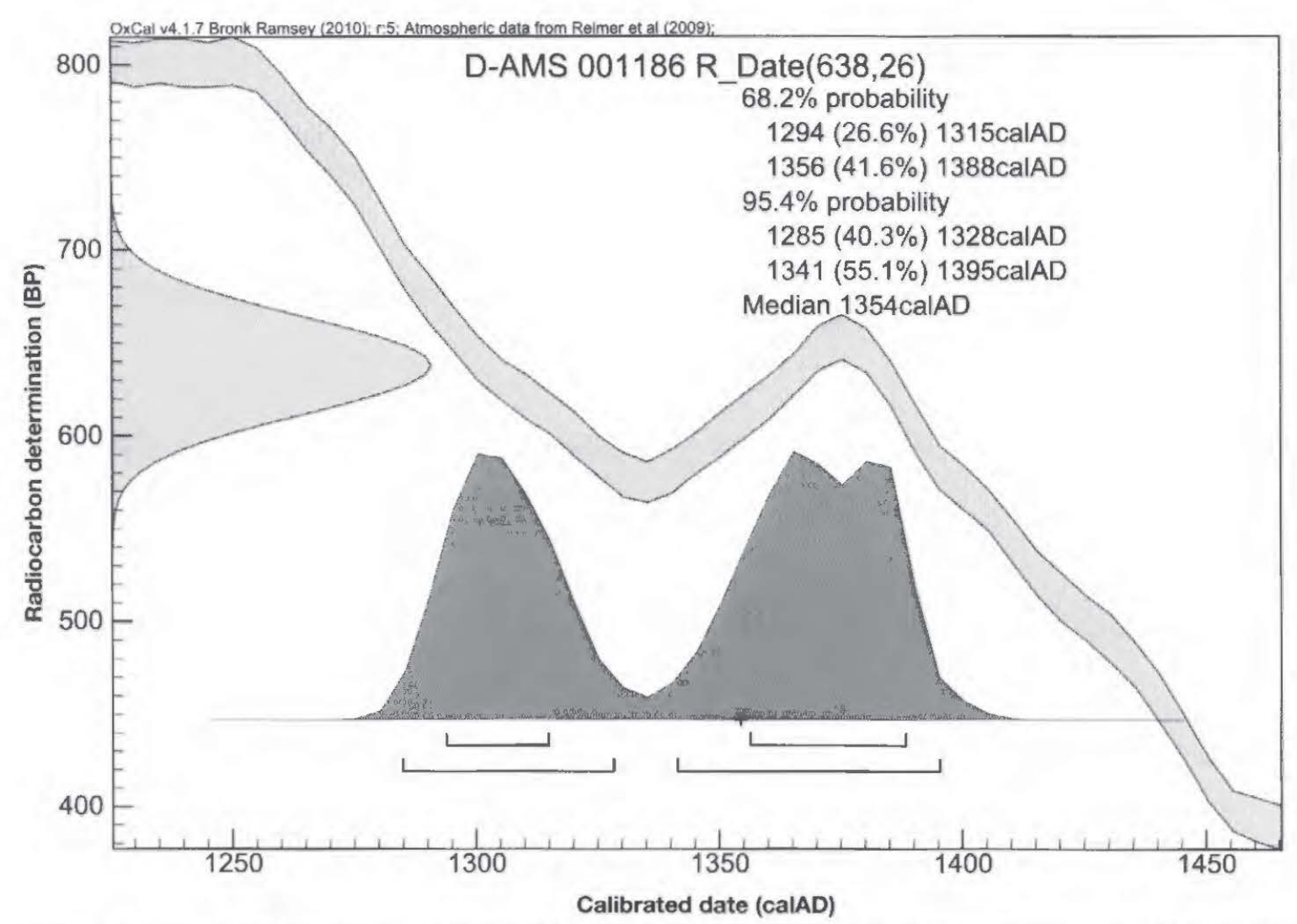

Figure 12. Calibrated age ranges of Burial 20, Vessel 2003.08.1042 organic residue from the Henry Williams site (AMS-001186).

\section{SUMMARY}

The seven new radiocarbon dates from these five Caddo sites in East Texas add to the ever increasing corpus of radiocarbon dates obtained from Caddo sites in the region (Selden and Perttula 2012). It was expected based upon the stylistic analysis of ceramic vessels from cemeteries at the Johns, Shelby Mound, Henry Spencer, and Henry Williams sites, as well as previously obtained radiocarbon dates from the Shelby Mound (Perttula et al. 2012a:Table 8) and Henry Spencer (Perttula et al. 2012b:Table 18 and Figure 309ab), that the six organic residue samples from these four sites would fall within the dated range of the Titus phase, ca. A.D. 1430-1680. The median calibrated ages of four of the samples are consistent chronologically with a Titus phase age, in that they range from A.D. 1498-1572. The other two organic residue samples, however, one from the Henry Spencer site and the other from the Henry Williams site, have calibrated mean ages of A.D. 1311 and A.D. 1354, respectively. Since these organic residues are from vessels in burials in cemeteries that have strong Titus phase associations, we have concluded that these calibrated age ranges are anomalously old.

The seventh, and final, calibrated date has been obtained from a sherd in a midden feature at the mid$18^{\text {th }}$ century Gilbert site. The median calibrated age of the organic residue from the sherd is A.D. 1745, fully meeting age expectations for the sample based on other artifacts recovered from the site, especially many European trade goods.

\section{ACKNOWLEDGMENTS}

We appreciate the permission of the Northeast Texas Community College, Tommy Johns, the Gregg County Historical Museum, and Jay Blaine to document the vessels and/or sherds from these five East Texas sites. 


\section{REFERENCES CITED}

Blaine, J. C.

1992 A Summary and Discussion of Additional Findings at the Gilbert Site, an Eighteenth-Century Norteno Occupation in Rains County, Texas. Bulletin of the Texas Archeological Society 63:175-196.

Bronk Ramsey, C.

2012 OxCal 4.1.7/ORAU. Electronic resource, https://c14.arch.ox.ac.uk/login/login.php'.I ocation=oxcal OxCal.html, accessed December 2012.

Jelks, E. B. (editor)

1967 The Gilbert Site: A Norteno Focus Site in Northeast Texas. Bulletin of the Texas Archeological Society 37:1-248.

Perttula, T. K.

2012 Analysis of Ceramic Sherds from the Mid-1 $8^{\text {th }}$ Century Gilbert Site on Lake Fork Creek, Rains County, Texas. Journal of Northeast Texas Archaeology 37:1-22.

Perttula, T. K., P. S. Marceaux, and B. Nelson

2012a Study of the Margaret Hinton Collection of Pottery Vessels from Northeast Texas Caddo Cemeteries. Special Publication No. 24. Friends of Northeast Texas Archaeology, Austin and Pittsburg.

Perttula, T. K., B. Nelson, and M. Walters

2012b Caddo Archaeology at the Henry Spencer Site (41UR315) in the Little Cypress Creek Basin of Eus Texas. Special Publication No. 20. Friends of Northeast Texas Archaeology, Pittsburg and Austin.

Perttula, T. K.. M. Walters, and B. Nelson

2010 Caddo Pottery Vessels and Pipes from the Johns Site (4ICPI2) in the Big Cypress Creek Basin in the Turner and Johns Collections, Camp County, Texas. Special Publication No. 11. Friends of Northeast Texas Archaeology, Austin and Pittsburg.

2012c Little Cypress Creek Basin Archaeology: Six Late Caddo Period Cemeteries in Upshur Counn; Texas. Special Publication No. 22. Friends of Northeast Texas Archaeology, Austin and Pittsburg.

Reimer, P. J., M. G. L. Baillie, E. Bard, A. Bayliss, J. W. Beck, P. G. Blackwell, C'. Bronk Ramı'?. C. E. Buck, G. S. Burr, R. L. Edwards, M. Friedrich, P. M. Grootes, T. P. Guilderson, I. Hajdas. Г J. Heaton, A. G. Hogg, K. A. Hughen, K. F. Kaiser, B. Kromer, F. G. McCormac, S. W. Manning R. W. Reimer, D. A. Richards, J. R. Southon, S. Talamo, C. S. M. Turney, J. van der Plicht, and C. E.Weyhenmeyer

2009 IntCal09 and Marine09 radiocarbon age calibration curves, 0-50,000 years cal BP. Radiocarhon 5/(4):1111-1150.

Selden, R. Z., Jr. and T. K. Perttula

2012 Radiocarbon Trends and the East Texas Caddo Tradition (ca. A.D. 800-1680). MS in review, Southeastern Archaeologv. 